\title{
INFORMATIKAI ALKALMAZÁSOK ÉS IT- SZAKEMBERIGÉNY ÖSSZEFÜGGÉSEI A MAGYARORSZÁGI VÁLLALKOZÁSOK KÖRÉBEN
}

\author{
Nagyné Halász Zsuzsanna - Gubán Miklós
}

\begin{abstract}
Absztrakt: A vállalkozások számára az információ az egyik legfontosabb erőforrás. Szükséges a szervezeti folyamatok kialakításához, hatékony müködtetéséhez, a döntéshozatalhoz, az üzleti környezettel való kapcsolattartáshoz, és a piaci szereplők befolyásolásához is. A piaci és jogszabályi környezet változásai megkövetelik a gyors és rugalmas alkalmazkodást, ami fejlett, hatékony információs rendszerek alkalmazása nélkül nem oldható meg. Az IT-alkalmazások kialakítása és működtetése az informatikai szakemberek feladata. Napjainkban a vállalkozások számára nagy problémát jelent a képzett informatikusok hiánya. Kutatásunk arra keres választ, hogy milyen tényezők befolyásolják a magyarországi társaságok IT-szakember igényét. A vállalkozások összességéből azért erre a célcsoportra esett a választás, mert az önálló vállalkozókra vonatkozó részletes adatbázist nem találtunk. Az informatikai szakemberek feladata az információs rendszerek kialakítása és müködtetése, így ebböl a nézőpontból vizsgáltuk a témát. Ugyanakkor több tanulmányban igazolták már, hogy az alkalmazott információs rendszer függ a vállalati mérettől. Így kutatásunk célja, hogy kimutassuk a vállalat méret, az alkalmazott információs rendszer és annak igénybevételi módjának hatását a vállalat IT-szakember igényére. Hipotéziseket állítottunk fel, melyeket empirikus kutatással vizsgáltunk. Az adatminta statisztikai elemzése alapján megállapítottuk, hogy a vállalat mérete hatással van az alkalmazott információs rendszer típusára, az igénybevétel módjára és az IT-szakemberek iránti keresletre is. Ha azonban arra a kérdésre keresünk választ, hogy a vállalati méret befolyásolja-e, hogy milyen informatikus-igény (rendszerfejlesztö, vagy üzemeltető) merül fel, akkor meg kell állapítanunk a két változó függetlenségét.

Az eredmények alapján kimutattuk, hogy a vállalkozásoknál alkalmazott információs rendszer típusa (ERP, vagy sziget rendszerek) hatással van az IT-szakemberigényre. Az igénybe vett IT-szolgáltatás típusa és az informatikus-igény között mintánk alapján nem mutatható ki kapcsolat.

Szakirodalmak prognosztizálják a felhő alapú szolgáltatások térhódítását. Így kutatásunkban külön vizsgáltuk ezt a szolgáltatási típust, hatását és megítélését.
\end{abstract}

\begin{abstract}
Information is one of the most significant resources of enterprises. It is vital to creating organisational processes, ensuring efficient operation, allowing for decision-making and liaison with their business environment and exerting influence on market players. Changes in market and legal conditions call for prompt and flexible adjustment, which is impossible in the absence of highlydeveloped and efficient information systems. IT professionals are responsible for developing and operating IT applications. Nowadays businesses are hit hard by the lack of qualified IT professionals. Our research strives to identify the factors influencing the demand of Hungarian companies for IT professionals. Our choice fell on this target group from the entirety of businesses since we could not find detailed databases on sole proprietorships. Considering that IT professionals are set the task of implementing and operating information systems, we have analysed the topic from this aspect. Nevertheless, several studies have confirmed that the information system applied depends on corporate size. Therefore, our research objective is to show the impact of corporate size, the information system used and the ways it is utilized on the company's demand for IT professionals. We formulated hypotheses that we investigated by empirical research. Based on the statistical analysis of the data sample we confirmed that corporate size in fact has a bearing on the type of information system used, and the manner of its utilisation as well as the demand for IT professionals. However, when we try to answer the question whether corporate size influences the kind of IT professionals needed (systems developer or operator), independence between the two variables must be confirmed. Our findings have confirmed that the type of information system in place at the enterprises (ERP, or 'island' systems) does influence the demand for IT professionals. Our sample does not allow for
\end{abstract}


identifying a relationship between the type of IT service used and the kind of IT professionals that are needed.

Technical literature forecasts the further spread of cloud-based services. Hence, we analysed such services, their impact and acceptance separately in our research.

Kulcsszavak: IT-szakemberigény, ERP, Felhő-szolgáltatás

Keywords: need for IT professionals, ERP, cloud services

\section{Bevezetés}

A vállalkozások számára az információ az egyik legfontosabb erőforrás. Szükséges a szervezeti folyamatok kialakításához, hatékony müködtetéséhez, a döntéshozatalhoz, az üzleti környezettel való kapcsolattartáshoz, és a piaci szereplök befolyásolásához is. Információ alatt az adatok feldolgozása és értelmezése eredményeként keletkező új ismeretet értjük. Segítségével csökkenthető az entrópia (bizonytalanság). (Nagyné-Gubán, 2016). Az adatok feldolgozását az információs rendszerek végzik, melyek kialakítása és működtetése az informatikai szakemberek feladata. A vállalkozások számára a piaci és jogszabályi környezet változásai miatt, egyre inkább nő a naprakész információk iránti igény, amely lehetővé teszi a gyors és rugalmas alkalmazkodást. Ez a szükséglet megköveteli a fejlett, hatékony információs rendszerek alkalmazását, így növekszik az informatikus-kereslet is. Napjainkban sokszor hallhatjuk médiákban, olvashatjuk a folyóiratokban, interneten, hogy az IT-szakemberek hiánya már olyan magas szintet ért el, ami már a vállalkozások müködésében is jelentős problémákat okoz. A helyzet súlyosságát mutatja az is, hogy központi kérdéssé vált az informatikus-képzés, és az informatikai tantárgyak oktatása. Ugyanakkor fontos feladat, hogy megismerjük a vállalkozások igényeit. Milyen IT-szakemberekre van szükség, és azok milyen kompetenciákkal rendelkezzenek. Kutatásunk is ezzel a témakörrel foglalkozik. Jelen tanulmányban arra a kérdésre keresünk választ, hogy milyen összefüggések állnak fenn a vállalatnál alkalmazott információs rendszerek és informatikus-szakemberigény között. A kapcsolódó szakirodalmi elemzés után bemutatjuk empirikus adatgyüjtésünk elemzését, ami 170 vállalkozás által kitöltött online kérdőív válaszai alapján végeztünk.

\section{Szakirodalmi áttekintés és az elméleti keret}

A téma elemzéséhez szükséges, az elméleti háttér bemutatása. A fejezetben az információs rendszer, információtechnológia (IT), IT-alkalmazások és azok igénybe vételi módja, valamint az IT munkakörök ismertetésével foglalkozunk.

\subsection{Információs rendszer, információrendszer, információtechnológia (IT)}

A szakirodalmakban különféle értelmezések jelennek meg az információs rendszer, információrendszer és információtechnológia vonatkozásában. Gyakran szinonimaként kezelik a fogalmakat. Információrendszer, vagy informatikai rendszer alatt az információtechnológia segítségével megvalósuló információgyüjtés, kezelés, feldolgozás, tárolás és megjelenítés tevékenységét értik. 
(Badinszky, 2011) (Chikán, 2008) (Raffai, 2003) (Szepesné, 2010). Ezeknél az elméleteknél nem csak azt tartjuk problémásnak, hogy egy aspektusból, a technológiai oldalról közelítik meg az információs rendszer fogalmát, hanem azt is, hogy szinonimaként kezelik az adat és információ fogalmát. Egy korábbi cikkünkben már szakirodalmakra alapozva bizonyítottuk, hogy a két fogalom eltér egymástól. (Nagyné, Gubán, 2016). Hasonló nézet szerint (Budd, 2011), az információ, jelentéssel bíró értelmezett adat, mely függ a kontextustól. Úgy véljük, az információs rendszer és információrendszer definíciója is különbözik egymástól.

Információs rendszer (IR) alatt a vállalati, és annak környezetéből származó, valamint a kettő kapcsolatából adódó tranzakcióknak, az őket leíró adatoknak, az információs tevékenységeknek és az erőforrásoknak (hardver, szoftver, menver/people, és szervezési/orgver eljárások) a szervezett együttesét értjük.

Hasonló meghatározásokat találunk több tanulmányban is. (Bocij et al., 2003) (Halassy, 1996) (Sziray, Gaul, 2006) (Kacsukné, Kiss, 2007) (Sasvári et al., 2014). Míg az információrendszer csupán az információs rendszer technikai alrendszere, ami az adatok gyüjtését, feldolgozását, tárolását, és továbbítását végző hardver és szoftver komponenseket foglalja magában. Találkozhatunk olyan értelmezéssel is, amely információs rendszer architektúra és technológiai architektúra fogalmakat használ (Kadre, 2011). Előbbi alatt a folyamatokat, adatokat és személyzetet, utóbbi alatt pedig hardver, szoftver feltételeket érti.

Az információrendszer szinonimájaként jelenik meg az információtechnológia (IT) fogalma. Hazai és nemzetközi statisztikákban, és némely szerzők tanulmányaiban megjelent az információs és kommunikációs technológia (IKT) fogalma, (Sasvári, 2010) (Badinszky, 2011). amely értelmezés szerint a hardver és szoftver mellett a kommunikáció is külön erőforrás. Véleményünk azokkal a szerzőkkel egyezik meg, akik kommunikációs technikát az IT részének tekintik. (Sziray, Gaul, 2006) (Bocij et al., 2003).

$\mathrm{Az}$ informatika és információtechnológia fogalmával sokszor azonos értelmezésben találkozhatunk (Sziray, Gaul 2006) (Hetyei, 1999, 2001), azaz csupán az adat- információ-feldolgozás hardver és szoftver erőforrásait jeleníti meg. Az információs rendszer technikai vonatkozásának tekintik. Az IT rövidítéssel is leginkább informatikai jelentésben találkozhatunk, mint például: IT-alkalmazások, IT-menedzsment. Így ebben a tanulmányban is ebben az értelmezésben használjuk az IT-szakemberek, azaz informatikai szakemberek fogalmát. Azonban a tágabb értelmezést tartjuk helyénvalónak, mely szerint az informatika az információs rendszerek létrehozásának, strukturálásának és müködtetésének a tudománya. (Szepesné, 2010).

\subsection{IT-alkalmazások funkciók szerinti kategorizálása}

Az információs rendszerek csoportosítása a szakirodalmakban, a szoftverek kategóriáinak meghatározását jelenti. Ezeket nevezik számítógép-alkalmazásoknak (Cser, Németh, 2007), vagy IT-alkalmazásoknak (Benkőné Deák, Bodnár, Gyurkó, 2008). A szoftverek csoportjait funkciók szerinti határozzák meg. A szerzők által meghatározott kategóriákat az 1. táblázatban foglaljuk össze. 


\section{1. táblázat: IT-alkalmazások}

\begin{tabular}{|c|c|}
\hline Név - Rövidített elnevezés & Funkció \\
\hline Transaction Processing System - TPS & Tranzakciófeldolgozó rendszer \\
\hline On-lineTransaction Processing - OLTP & Valós idejű tranzakció-feldolgozás \\
\hline Office Automatization Systems - OAS & Irodaautomatizálási rendszerek \\
\hline WorkFlow System - WS & Munkafolyamat szabályozás \\
\hline Data Warehouse - DW & Adattárház \\
\hline Customer Relationship Management - CRM & Ügyfél- és vevőkapcsolat-menedzsment \\
\hline Supply Chain Management - SCM & Ellátási lánc-menedzsment \\
\hline Supplier Relationship Management - SRM & Beszállítói kapcsolat-kezelő rendszer \\
\hline Expert System - ES & Szakértői rendszerek \\
\hline Group Support Systems — GSS & Csoportmunka támogató rendszer \\
\hline Knowledge (Management) System - KWS (KMS ) & Tudás(menedzsment) alapú rendszer \\
\hline Enterprise Performance Management - EPM & Vállalati teljesítménymenedzsment \\
\hline Production Planning and Scheduling - PPS & Termeléstervezés \\
\hline Materials Requirements Planning - MRPI. & Anyagszükséglet tervezés \\
\hline Materials Requirements Planning - MRPII. & Teljes gyártási szükséglet tervezése \\
\hline Geographical Information Systems - GIS & Térinformatikai rendszerek \\
\hline Computer Integrated Manufacturing - CIM & Számítógéppel integrált gyártás \\
\hline Computer Aided Design - CAD & Gyártmánytervezés \\
\hline Computer Aided Engineering - CAE & Számítógéppel támogatott fejlesztés \\
\hline Computer Aided Production Planning - CAP & Számítógéppel támogatott gyártástervezés \\
\hline Computer Aided Manufacturing - CAM & Számítógéppel támogatott gyártás \\
\hline Computer Aided Quality Assurance - CAQ & Számítógéppel támogatott minőségbiztosítás \\
\hline Management Information System - MIS, VIR & Vezetői információs rendszer \\
\hline Executive Information System - EIS & Felsővezetői információs rendszer \\
\hline (Group) Decision Support System - (G)DSS & (Csoportos) Döntéstámogató rendszer \\
\hline On-line Analytical Processing - OLAP & On-line elemző rendszerek \\
\hline Business Intelligence - BI & Üzleti intelligencia \\
\hline Enterprise Resources Planning - ERP & Vállalati erőforrás-tervezés \\
\hline Total Enterprise Integration - ERP II. & Teljes vállalatirányítási rendszer \\
\hline Integrated Enterprise Application - IEA & Integrált vállalatirányítási alkalmazások \\
\hline
\end{tabular}

Forrás: Saját szerkesztés / Koloszár (2013)

Kutatásunkban is felhasználjuk az IT-alkalmazások táblázat szerinti kategóriáit a vállalatok információs rendszerének felmérése során, de kiszürtük az egymást fedő elnevezéseket, és funkciócsoportokat is létrehoztunk. Az informatikai alkalmazások körében minőségi ugrást jelentett az integrált rendszerek megjelenése. A szakirodalmakban az ERP rendszereket nevezik integrált vállalatirányítási rendszereknek (Giller, 2014), vagy integrált vállalatirányítási információs rendszereknek (Hetyei, 1999). Az üzleti tranzakciókat egységesen kezelik, tervezik az erőforrásokat és kiszolgálják a megfelelö vezetői szinteket, így megvalósítják a vertikális és horizontális integrációt is (Nicolescu et al., 2007). Az ERP rendszerek jellemzője, a moduláris szerkezet, közös adatbázisra építve. 
A gyakorlatban és egyes szakirodalmakban azonban olyan szoftvereket is ERPnek neveznek, melyek nem fedik le a teljes integrációs területet. (Kadre, 2011) (Cser, Németh, 2007). Kutatásunkban is foglalkoztunk az integrált rendszerek értelmezésével.

Több szerző igazolta tanulmányában, hogy a vállalat mérete és alkalmazott információs rendszer között összefüggés áll fenn (Sasvári, Rauch, Szabó, 2014) (Koloszár, 2009). Kutatásunk során elfogadtuk ezt a megállapítást, és figyelembe vettük a vállalati méret szerinti csoportosítást az IT-szakember igény elemzésénél.

\subsection{Információs rendszerek kialakításának lehetőségei a vállalkozásoknál}

Az információs rendszerek fejlesztése során a vállalkozásoknak dönteniük kell arról, hogy milyen módon biztosítják az adatok feldolgozásához szükséges szoftvereket. Az IT-alkalmazások forrása lehet (Komló, 2013):

- Saját fejlesztés, a vállalat speciális igényei alapján.

- IT cég segítségével megvalósított fejlesztés. Ennél a megoldásnál a fejlesztő cég keretrendszerét alakítják a vállalat igényei szerint.

- IT cégek által elöre elkészített szoftvercsomagok ún. dobozos rendszerek igénybevétele, melyeket modell vállalat alapján standard folyamatokra alakítottak ki.

- Outsourcing esetén egy informatikai cég hardveres és/vagy szoftveres szolgáltatásokat nyújt egy másik cég információs rendszerének müködtetésére. A szolgáltatás a szakember biztosításától a teljes kiszervezésig terjedhet.

Az IT-szolgáltatások igénybe vehetők az interneten keresztül elérhető számítási felhöböl (Cloud Computing) is. Három szintet különböztethetünk meg:

1. Infrastruktúra - Infrastructure as a Service (IaaS).

2. Fejlesztöi környezet - Platform as a Service (PaaS).

3. Adatfeldolgozó (alkalmazói) szoftver szolgáltatása - Software as a Service (SaaS).

A felhőszolgáltatások megítélése a szakirodalmakban is különböző. Általában elfogadott az a megállapítás, hogy az IT kialakításának befektetés igénye alacsonyabb, az üzemeltetési költségek csökkennek, és az igénybe vett szolgáltatás is skálázható, cégre szabható. (Szabó et al., 2013) (Repschläger, Zarnekow, 2011) (Komló, 2013). Ugyanakkor a biztonság, rendelkezésre állás, mint előny már csak néhány szerzőnél jelenik meg. Sőt, vannak olyan tanulmány is, ahol biztonsági kockázatként szerepel, mert kikerülnek a vállalat adatai a szolgáltató cég tárolóira. (Komló, 2013) (Szabó et al., 2013). Hátrányt jelenthet a szolgáltatótól való függés, és a nem megfelelő jogi szabályozás, és lassú hozzáférés is. Ugyanakkor a jövőben nagy potenciált jelenthet a felhőszolgáltatás a KKV-k számára.

Az eltérő megítélés miatt kutatásunkban is foglalkoztunk a számítási felhő vállalatok általi megítélésének kérdésével, illetve az egyes szinteken történő használatával. 
2.4. Informatikus munkakörök az EU keretrendszerének ajánlása és magyarországi vállalkozási igények szerint

$\mathrm{Az}$ informatikai munkakörökre vonatkozóan az Európai Bizottság egységes nómenklatúrát, az „European e-Competence Framework 3.0” (röviden: e-CF 3.0) keretrendszert alakított ki 2012-2013-ban. A 120 stakeholders által elfogadott rendszerben kialakult egy 23 munkakört felölelő IKT profil rendszer, amelyet 6 csoportba soroltak. 2018-ban kiegészítették a listát. 30 munkakör került meghatározásra, 7 csoportba sorolva (lásd: 2. táblázat).

\section{2. táblázat: European ICT Profile}

\begin{tabular}{|c|c|}
\hline Families & ICT Profiles \\
\hline \multirow[t]{4}{*}{ Process Improvement (Folyamat-fejlesztés) } & Digital Transformation Leader (Digitális Átalakítás-irányító) \\
\hline & Product Owner (Termékgazda) \\
\hline & Scrum Master (Scrum-Mester) \\
\hline & DevOps Expert (DevOps Szakértő) \\
\hline \multirow[t]{4}{*}{ Business (Üzlet) } & Business Information Manager (Üzleti Információ Menedzser) \\
\hline & Cief Information Officer (Információs rendszer Vezető) \\
\hline & ICT Operations Manager (ICT Folyamat-menedzser) \\
\hline & Data Scientist (Adat-tudós) \\
\hline \multirow[t]{5}{*}{ Technical (Müszaki) } & Quality Assurance Manager (Minőségbiztosítási menedzser) \\
\hline & Cyber Security Manager (Kiberbiztonsági Vezető) \\
\hline & Project Manager (Projekt-menedzser) \\
\hline & Service Manager (Szerviz-menedzser) \\
\hline & Data Specialist (Adat-Specialista) \\
\hline \multirow[t]{5}{*}{ Design (Tervezés) } & Business Analyst (Üzleti elemző) \\
\hline & Systems Analyst (Rendszer-elemző) \\
\hline & Enterprise Architect (Szervezeti struktúra tervező) \\
\hline & Systems Architect (Rendszertervezö) \\
\hline & Solution Designer (Megoldás-tervező) \\
\hline \multirow[t]{3}{*}{ Development (Fejlesztés) } & Developer (Fejlesztő) \\
\hline & Digital Media Specialist (Elektronikus média szakértő) \\
\hline & Test Specialist (Tesztelő) \\
\hline \multirow[t]{5}{*}{ Service \& Operation (Szerviz és Folyamatok) } & Data Administrator (Adat adminisztrátor) \\
\hline & Systems Administrator (Rendszer adminisztrátor) \\
\hline & Network Specialist (Hálózati szakértő) \\
\hline & Technical Specialist (Műszaki szakértő) \\
\hline & Service Support (Szerviz-támogatás) \\
\hline \multirow[t]{4}{*}{ Support (Támogatás) } & Account Manager (Számla-vezető) \\
\hline & Digital Educator (Digitális oktató) \\
\hline & Cyber Security Specialist (Kiberbiztonsági szakértő) \\
\hline & Digital Consultant (Digitális tanácsadó) \\
\hline
\end{tabular}

Forrás: Saját szerkesztés / Breyer (2018) 
A magyar vállalkozások IT-szakember igénye munkakörök szerint (Szabó, 2013):

- adminisztrátor (administrator);

- $\quad$ üzemeltető operátor (operator);

- $\quad$ fejlesztő, programozó (developer);

- menedzser, vezető (manager);

- mérnök (engineer);

- $\quad$ konzulens, tanácsadó (consultant);

- szakértő (expert), kulcsfelhasználó (key user), specialista;

- $\quad$ szervezö, elemzö (analyst);

- rendszergazda (system administrator);

- $\quad$ ügyfélkapcsolati szerepkör (customer support, help desk, customer service);

- technikus (technician);

- tesztelö (tester);

- architekt.

Kutatásunkban szakirodalmak alapján a szakembereket rendszerfejlesztő és rendszerüzemeltető föcsoportra bontottuk, majd ezen belül munkakör csoportokat határoztunk meg.

\subsection{Kutatási cél, kutatási hipotézisek}

A kutatás célja, hogy bemutassa a vállalatok informatikai szakemberigényét befolyásoló tényezőket. A témát a vállalati információs rendszer oldaláról vizsgáltuk. A szakirodalmi elemzés után hipotéziseket állítottunk fel (lásd: 3. táblázat).

\section{3. táblázat: Hipotézisek}

\begin{tabular}{|c|c|}
\hline $\begin{array}{l}\text { Hipotézis } \\
\text { sorszáma }\end{array}$ & Hipotézis tartalma \\
\hline 1. & $\begin{array}{c}\text { Feltételezzük, hogy a vállalati méret befolyásolja, az ERP rendszerek } \\
\text { használatát. }\end{array}$ \\
\hline 2. & $\begin{array}{l}\text { Feltételezzük, hogy a vállalati méret befolyásolja, hogy milyen módon } \\
\text { történik az IT-alkalmazás igénybe vétele. }\end{array}$ \\
\hline 3. & $\begin{array}{c}\text { Feltételezzük, hogy a vállalati méret meghatározza azt, hogy szükség van-e } \\
\text { informatikusra. }\end{array}$ \\
\hline 4. & $\begin{array}{c}\text { Feltételezzük, hogy az IT szolgáltatások igénybe vétele hatással van az IT } \\
\text { szakemberigényre. }\end{array}$ \\
\hline
\end{tabular}

Forrás: Saját szerkesztés

Hipotéziseink igazolására empirikus adatgyüjtést végeztünk a magyar társas vállalkozásokra vonatkozóan, majd kvantitatív elemzés után értékeltük az eredményeket. A kvantitatív kutatással számszerü, mérhető adatok alapján oksági összefüggéseket tárunk fel, melyet általánosítunk az alapsokaságra. (Sajtos, Mitev, 2007). 


\section{Módszertan}

\subsection{Adatgyüjtés}

Az empirikus kutatással 2017.09.01. - 2019.02.28. időtartam alatt a magyarországi társaságok körét választottuk célcsoportnak, mert az önálló vállalkozókra vonatkozó részletes adatbázist nem találtunk. A mintavétel az EMIS adatbázisból valósult meg, ami az országban müködő összes társas vállalkozás mintegy $10 \%$-áról tartalmaz részletes létszám és gazdasági adatokat. A minta kiválasztásánál a megbízható következtetések levonása érdekében biztosítani kell a véletlen mintavételt. (Babbie, 2013). A kvantitatív adatgyüjtésnél a nagy minta, és a véletlen mintavétel szükséges a statisztikai elemzésekhez és általánosíthatósághoz. (Horváth, Mitev, 2015). Az adatgyüjtéshez online kérdőívet alkalmaztunk, mely Google Ürlapként került kialakításra. A megoldásnak egyik legnagyobb előnye, hogy a kitöltő válaszai alapján irányítható a kérdések sorrendje, így növelhető az kitöltés hatékonysága. Hátrány viszont, hogy nagyon alacsony a kitöltési hajlandóság, amit ismételt felkéréssel növeltünk. A kérdőív összeállítását irodalomkutatás előzze meg, melynek témaköreivel az előző fejezetben találkozhattunk.

A hibák, félreérthető kérdések és a kérdések közötti nem megfelelő ugrások, kiküszöbölése próbakérdezést célszerü végezni. (Babbie 2013). Így az online adatgyüjtést megelőzően ismerős vállalkozásokkal, szakemberekkel próbakitöltést valósítottunk meg. A visszajelzések alapján a kérdőív újabb és újabb változatai kerültek kidolgozásra az értelmezési és szerkezeti problémák kiküszöbölése érdekében. Miután a végleges változat elkészült, meg kellett határoznunk a mintában szereplő vállalkozások körét.

Célunk a 100 kitöltött kérdöív elérése volt. Az online kiküldés miatt alacsony, 10\%-os visszaküldési aránnyal számoltunk. A célként kitüzött 100 kitöltött kérdőíves igényhez tehát 1000 elemből álló mintát kellett kiválasztanunk. A minta kiválasztásánál törekedtünk a reprezentativitásra. Kutatásunkban a vállalati méret, mint változó hatásait több nézőpontból is vizsgáltuk, így az alkalmazottak száma szerinti vállalati csoportok megoszlását alkalmaztuk a reprezentativitás érdekében a mintaelemek meghatározásánál.

A mikro-, kis- és középvállalkozások (a továbbiakban: $\mathrm{KKV}$ ) vállalati méretének létszám és árbevétel szerinti csoportosítását a 2004. évi XXXIV. törvény határozza meg. Értelmezése szerint:

- Mikrovállalkozásnak minősül az a vállalkozás, amelynél az összes foglalkoztatott létszáma 10 főnél kevesebb, és éves nettó árbevétele vagy mérlegföösszege legfeljebb 2 millió eurónak megfelelö forintösszeg.

- Kisvállalkozásnak minősül az a vállalkozás, amelynél az összes foglalkoztatott létszáma 10 és 49 fö közötti, és éves nettó árbevétele vagy mérlegföösszege legfeljebb 10 millió eurónak megfelelö - de minimum 2 millió eurónak megfelelö - forintösszeg.

- Középvállalkozásnak minősül az a vállalkozás, amelynél az összes foglalkoztatott létszáma 50 és 249 fő közötti, és éves nettó árbevétele 
legfeljebb 50 millió eurónak megfelelő - de minimum 10 millió eurónak megfelelő - forintösszeg.

A reprezentatív mintavételhez a KSH adatbázisát használtuk. Az adatgyüjtés 2017-ben kezdődött, így a 2016. év végi megoszlással dolgoztunk. A KSH adatbázis a kisvállalkozásokat tovább bontja 10-19 és 20-49 fős csoportokra. A 2004. évi XXXIV. törvény értelmében a két csoportot összevontuk.

A vállalkozások jellemzöi területenként eltérhetnek, ezért a mintavételnél a társas vállalkozások megye és régió szerinti eloszlását is figyelembe vettük. Az EMIS adatbázis lehetőséget adott arra, hogy a működő társas vállalkozásokat létszám és megye szerint is szürjük. Az így kapott részsokaságokból az Excel programmal meghatározott véletlen sorszámok alapján kerültek kiválasztásra a minta elemei, amely vállalkozásoktól az adatgyüjtés megvalósult. A kérdőívet, a válaszadót egyéni kitöltésre felkérő e-mailben, linkkel ellátva küldtük ki a cégeknek.

A kézbesítetlen e-mailek helyett újakat küldtünk ki. Az önkitöltés azonban nagyon alacsony kitöltési arányt eredményezett. Mintegy 1800 sikeresen elküldött e-mail után kevesebb, mint 100 értékelhető, kitöltött kérdőív érkezett be a többfordulós lebonyolítás után is. Így kérdezőbiztosokat vetettünk be, melynek eredményeként, a hibásak kiszürése után 170 kérdőív adatai kerültek felrögzítésre. Megkezdődhetett az adatok elemzése.

\subsection{Adatok feldolgozása}

A 170 kérdőív elemzése során megállapítottuk, hogy a reprezentatív mintavétel, mint célkitüzés nem valósult meg, a minta vállalkozások megoszlása eltért a sokasági megoszlástól (lásd: 4. táblázat).

\section{4. táblázat: A regisztrált társas vállalkozások száma és megoszlása létszám- kategóriák szerint a magyarországi sokaságban (KSH) és a mintában}

\begin{tabular}{|c|c|c|c|}
\hline \multirow{2}{*}{$\begin{array}{c}\text { Létszám-kategóriák } \\
(\text { Fö })\end{array}$} & \multicolumn{2}{|c|}{ A sokaságban 2016.12.31 } & A mintában 2019.02.28. \\
\cline { 2 - 4 } & Alkalmazottak száma (Fö) & Megoszlás (\%) & Megoszlás (\%) \\
\hline $0-9$ & 505679 & 93,5 & 26,5 \\
\hline $10-19$ & 18943 & 3,5 & \\
\hline $20-49$ & 10141 & 1,9 & \\
\hline $10-49$ & 29084 & 5,4 & 37,1 \\
\hline $50-249$ & 4899 & 0,9 & 18,2 \\
\hline 250 és több & 923 & 0,2 & 18,2 \\
\hline Összesen & 540585 & 100,0 & 100,0 \\
\hline
\end{tabular}

Forrás: Saját szerkesztés

A kitöltött kérdőívek területi és tevékenységi kör szerinti megoszlását vizsgálva megállapítható, hogy leginkább a Nyugat-dunántúli $(43,5 \%)$ és budapesti $(44,1 \%)$ vállalkozások töltötték ki a kérdőívet. A kitöltő vállalkozások a nemzetgazdaság valamennyi ágazatát képviselik a mintában. 
Bár a vállalati méret szerinti reprezentativitás igénye nem teljesült, a minta nagysága és az elemek kiválasztásának módja lehetővé teszi statisztikai elemzések megvalósítását, következtetések levonását. A kérdőíveket SPSS programmal értékeltük ki. A felvetett hipotéziseinkhez felhasznált 170 elemü minta nagynak számít.

\section{Eredmények és értékelésük}

\subsection{Hipotézisünk}

Feltételeztük, hogy a vállalati méret befolyásolja, az ERP rendszerek használatát. A kapcsolat vizsgálatát alacsony szintủ változók esetén Kereszttábla-elemzéssel végezzük. A nullhipotézis $\left(\mathrm{H}_{0}\right)$ szerint a két változó között nincs kapcsolat. A Pearson-féle Khi-négyzet statisztika alapján el kell utasítanunk a nullhipotézist, mert a számított szignifikancia érték nem éri el a 0,05 szignifikancia szintet, így a nullhipotézist elutasítjuk. Szignifikáns kapcsolat van a vállalati méret és az ERP használat között. A Kramer V mutató közepesen erős asszociációs kapcsolatot mutat.

A Lambda asszociációs érték alapján, ha ismerjük a vállalati méretet, akkor 30,9\%-ban elöre jelezhető, hogy alkalmaznak-e ERP rendszer-t. Az Adjusted Residuál (Korrigált maradék) érték a mikrovállalkozásoknál -2-nél kisebb, így a méret és az ERP rendszer változók között kimondott, szignifikáns taszítás figyelhető meg. A közepes és nagy vállalatoknál a Korrigált maradék érték 2-nél nagyobb, ami a változók közötti szignifikáns vonzást fejezi ki (lásd: 5. táblázat).

5. táblázat: Kereszttábla-elemzés

\begin{tabular}{|c|c|}
\hline Kereszttábla elemzés SPSS mutatói & Értékek \\
\hline Person-féle Khi-négyzet statisztika & 0,000 \\
\hline Kramer V & 0,504 \\
\hline Lambda asszociációs érték & 0,309 \\
\hline Korrigált maradék (Mikrovállalkozás), ha van ERP & $-5,3$ \\
\hline Korrigált maradék (Középvállalkozás), ha van ERP & 3,0 \\
\hline Korrigált maradék (Nagyvállalat), ha van ERP & 4,2 \\
\hline
\end{tabular}

Forrás: Saját kutatás, SPSS

$\mathrm{Az}$ 1. hipotézisünket az elemzés alapján elfogadjuk, a vállalati méret befolyásolja, hogy alkalmaz-e ERP rendszer a vállalkozás.

A mintában szereplő vállalkozások $40 \%$-a nem használ ERP rendszert. Ennek okaként egyrészt a vállalkozás méretét $(62,1 \%)$, másrészt a tevékenységi kört $(20,0)$ jelölték meg leggyakrabban. A külső szolgáltatók igénybe vétele csupán az ERP-t nem használók 8,6 \%-ánál jelent meg. Az integrált vállalatirányítási rendszer hiánya nem jelenti azt, hogy a vállalkozás nem müködnek szoftverek. Az ERP-t nem használók 83,1 \%-ánál üzletviteli, 62,9 \%-ánál office, 44,3 \%-ánál hálózati, 33,3 \%ánál adatbáziskezelő rendszereket alkalmaznak. Ha összehasonlítjuk az 
eredményeket korábbi, ugyanezen területre vonatkozó tanulmánnyal (Sasvári, 2013), akkor jelentős javulást tapasztalhatunk.

Az ERP rendszereket alkalmazó vállalkozásoknál megfigyelhető, hogy a horizontális és vertikális integráció nem érvényesül maradéktalanul. Ezt bizonyítja az, hogy 65,7 \%-uknál az integrált rendszerek mellett más szoftvereket is alkalmaznak az üzleti tevékenységek támogatására.

\subsection{Hipotézisünk}

Feltételeztük, hogy a vállalati méret befolyásolja, hogy milyen módon történik az ITalkalmazás igénybe vétele. A nullhipotézis $\left(\mathrm{H}_{0}\right)$ szerint a két változó között nincs kapcsolat. A Pearson-féle Khi-négyzet statisztika alapján el kell utasítanunk a nullhipotézist, mert a számított szignifikancia érték nem éri el a 0,05 szignifikancia szintet, így a nullhipotézist elutasítjuk. Szignifikáns kapcsolat van a vállalati méret és az ERP használat között. A Kramer V mutató gyenge asszociációs kapcsolatot mutat.

A Lambda asszociációs érték alapján, ha ismerjük a vállalati méretet, akkor 12,1 \%-ban előre jelezhető a szoftver igénybe vétel módja. Az Adjusted Residuál (Korrigált maradék) érték a mikrovállalkozásoknál -2-nél kisebb az IT cégek által a cégigények beépítésével történő fejlesztésnél, így a változók között kimondott, szignifikáns taszítás figyelhető meg. Ugyanakkor ennél a vállalkozási méretnél az IT cégek ún. „dobozos” rendszerének bevezetése típusnál, a Korrigált maradék érték 2nél nagyobb, így a változók között szignifikáns vonzás figyelhető meg. A nagyvállalatoknál a Korrigált maradék érték 2-nél nagyobb az IT cégek által a cégigények beépítésével történő fejlesztésnél, ami a változók közötti szignifikáns vonzást fejezi ki. Kis és középvállalatoknál mintánk alapján a szignifikáns vonzástaszítás nem állapítható meg (lásd: 6. táblázat).

\section{6. táblázat: Kereszttábla-elemzés}

\begin{tabular}{|c|c|}
\hline Kereszttábla elemzés SPSS mutatói & Értékek \\
\hline Person-féle Khi-négyzet statisztika & 0,040 \\
\hline Kramer V & 0,200 \\
\hline Lambda asszociációs érték & 0,121 \\
\hline Korrigált maradék (Mikrovállalkozás), IT cég fejleszt... & $-2,7$ \\
\hline Korrigált maradék (Mikrovállalkozás), IT cég dobozos... & 2,6 \\
\hline Korrigált maradék (Nagyvállalat), IT cég fejleszt... & 2,7 \\
\hline
\end{tabular}

Forrás: Saját kutatás, SPSS

\subsection{Hipotézisünk}

Hipotézisünkben azt feltételezzük, hogy a vállalati méret meghatározza azt, hogy szükség van-e informatikusra. A kapcsolat feltárása érdekében itt is kereszttábla elemzés alkalmazható. A nullhipotézis $\left(\mathrm{H}_{0}\right)$ szerint a két változó között nincs kapcsolat. A Pearson-féle Khi-négyzet statisztika szerint el kell utasítanunk a 
nullhipotézist, mert a számított szignifikancia értéke 0,00 kisebb, mint az elfogadható 0,05-ös szint. Szignifikáns kapcsolat van a vállalati méret és az ITszakember igény között. A Kramer V mutató értéke $(0,511)$ közepesen szoros asszociációs kapcsolatot mutat. Talán az egyértelmü, hogy a vállalati méret növekedésével nagyobb az igény az IT-szakemberek iránt. Az azonban már érdekesebb kérdés, hogy melyik szakembercsoportra van szükség. Hiszen azt gondolhatnánk, hogy a kisebb vállalkozói mérethez inkább az üzemeltetők iránti igény jelenik meg. A kapcsolat a vállalati méret és az IT szakembercsoport között Kereszttábla-elemzéssel vizsgálható. A Pearson-féle Khi-négyzet statisztika számításakor azt tapasztaltuk, hogy a számított szignifikancia értéke 0,947 nagyobb, mint az elfogadható 0,05-ös szint. Így el kell fogadnunk a nullhipotézist, nincs szignifikáns kapcsolat a vállalati méret és a szükséges IT-szakembercsoport iránti igény között. Ha részletesen elemezzük a Kereszttáblát, akkor számításaink azt mutatják, hogy egyetlen vállalati méretnél sem jelenthetjük ki, hogy csak üzemeltetőkre, fejlesztőkre, esetleg mindkettőre lenne szükség.

\subsection{Hipotézisünk}

Feltételeztük, hogy az IT-szolgáltatások igénybe vétele hatással van az IT-szakember igényre.

Először arra a kérdésre keresünk választ, hogy az ERP rendszer alkalmazása, és az informatikus-igény között van-e összefüggés. Evidenciaként megállapítható, hogy minél bonyolultabb a vállalatnál alkalmazott információs rendszer (IR), annál nagyobb a szakemberigény. A kereszttábla elemzéssel is kimutatható a közepesen erős asszociációs kapcsolat az ERP rendszerek alkalmazása és az IT-szakemberigény között, de két dichotóm változó ( 0,1 típusú) közötti kapcsolat vizsgálatára végezhetö Cochran és Mantel-Haenszel statisztika is. (Fliszár, Bollók, 2014). A mutató szignifikáns kapcsolatot jelez. Számított szignifikancia értékünk 0,00, ami kisebb a megengedett 0,05 szintnél. Így elvetjük a változók függetlenségét feltételező nullhipotézist.

Ugyanakkor a vállalkozások informatikus szakember-igényüket nemcsak alkalmazottak felvételével elégíthetik ki, hanem igénybe vehetnek IT cégek által kínált szolgáltatásokat is. A felhőszolgáltatások megjelenése az infrastrukturális egyenlötlenségek áthidalását is lehetővé teszi. A következö részben a vizsgálat arra terjed ki, hogy az igénybe vett IT-szolgáltatások hogyan befolyásolják az informatikus-igényt.

Először érdemes vizsgálni, hogy a vállalati méret befolyásolja-e az igénybe vett szolgáltatási formát.

A kereszttábla-elemzések során megállapítható, hogy a vállalati mérettől szignifikánsan nem függ, hogy vesznek-e igénybe a vállalkozások ITszolgáltatásokat, vagy felhő alapú szolgáltatást. A kiszámított Pearson-féle Khinégyzet szignifikancia értéke 0,746 a vállalati méret és igénybe vett ITszolgáltatások kapcsolatában, ami meghaladja 0,05 értéket, ezért el kell fogadnunk a nullhipotézist, a változók függetlenségét. 
Ha azonban arra a kérdésre keresünk választ, hogy van-e kapcsolat a vállalati méret és igénybe vett IT-szolgáltatási típus között, akkor már árnyaltabb a kép (lásd: 7. táblázat).

7. táblázat: Kereszttábla-elemzés

\begin{tabular}{|c|c|}
\hline Kereszttábla elemzés SPSS mutatói & Értékek \\
\hline Person-féle Khi-négyzet statisztika & 0,016 \\
\hline Kramer V & 0,249 \\
\hline Korrigált maradék (Mikrovállalkozás), csak IT-szakembert & 2,0 \\
\hline Korrigált maradék (Kisvállalkozás), Infrastruktúrát és szakembert & 2,1 \\
\hline Korrigált maradék (Kisvállalkozás), Mindent & $-2,4$ \\
\hline Korrigált maradék (Nagyvállalat), csak IT-szakembert & $-3,1$ \\
\hline
\end{tabular}

Forrás: Saját kutatás, SPSS

A vállalati méret és igénybe vett IT-szolgáltatási típus közötti kapcsolat feltárása érdekében itt is kereszttábla elemzés alkalmazható. A nullhipotézis $\left(\mathrm{H}_{0}\right)$ szerint a két változó között nincs kapcsolat. A Pearson-féle Khi-négyzet statisztika szerint el kell utasítanunk a nullhipotézist, mert a számított szignifikancia értéke kisebb, mint 0,05. Szignifikáns kapcsolat van a vállalati méret és az IT-szolgáltatás típusa között. A Kramer V mutató értéke gyenge asszociációs kapcsolatot mutat.

A kereszttábla megoszlás szerinti vizsgálatakor a Korrigált Maradék érték alapján a megállapítható, hogy nagyvállalati méret és a csak IT-szakemberek igénybe vétele változók között szignifikáns taszítás jelentkezik. A kisvállalkozási méret és a teljes IT outsourcing, mint változók között is szignifikáns taszítást figyelhetünk meg. Ugyanakkor a mikrovállalkozási méret és a csak IT-szakember változói között szignifikáns vonzást mutat a Korrigált maradék érték. A kisvállalkozási méret, valamint az infrastruktúra és szakember igénybe vétele változók között jelentkezik a vonzás.

A vállalati méret és felhő alapú szolgáltatások kapcsolatának vizsgálata során megállapítható, hogy a két változó között nincs szignifikáns kapcsolat. A kiszámított Pearson-féle Khi-négyzet szignifikancia értéke 0,739, ami meghaladja 0,05 szintet, ezért el kell fogadnunk a nullhipotézist, a változók függetlenségét. Ugyancsak függetlenséget állapíthatunk meg a vállalati méret, és az igénybe vett felhőszolgáltatás típusa között. A Pearson-féle Khi-négyzet szignifikancia értéke 0,458. Megállapíthatjuk tehát, hogy egy mikrovállalkozásoknál ugyanúgy előfordulhat a felhő alapú szolgáltatás igénybe vétele, bármelyik formáját is alkalmazzák, mint egy nagyvállalatnál. A kereszttábla-elemzéssel nem mutatható ki szignifikáns vonzás, vagy taszítás.

A negyedik hipotézisünkben az igénybe vett IT-, vagy felhőszolgáltatás típusa és a szakemberigény közötti kapcsolatot feltételeztük. Az összefüggés elemzése során vizsgáltuk, hogy az igénybe vett szolgáltatási típus mellett van-e szükség informatikusra, és ha igen, akkor melyik szakembercsoportra. Feltételezhető, hogy 
ha a vállalkozás kihelyezi (outsourcing) az informatikai tevékenységeket külső szolgáltatóknak, akkor nem lesz szüksége IT- szakemberre.

A kereszttábla-elemzés során mintánk alapján megállapítható, hogy az ITszolgáltatás igénybe vétele és IT-szakember szükséglet között nincs szignifikáns kapcsolat. A kiszámított Pearson-féle Khi-négyzet szignifikancia értéke 0,526, ami meghaladja a 0,05 értéket. Így el kell fogadnunk a nullhipotézist, a változók függetlenségét. Az igénybe vett IT-szolgáltatás típusa, és az IT-szakember szükséglet vonatkozásában is el kell fogadnunk a nullhipotézist, a változók függetlenségét. A kiszámított Pearson-féle Khi-négyzet szignifikancia értéke 0,474, ami meghaladja a 0,05 értéket. Nem igazolódott az a feltételezésünk (4. hipotézis), hogy az informatikai tevékenységek kiszervezése esetén nincs szükség ITszakemberre. Amennyiben a vállalkozás felhő alapú szolgáltatást vesz igénybe, a Kereszttábla elemzés hasonló eredményeket igazol. Nincs szignifikáns kapcsolat sem a felhőszolgáltatás igénybe vétele, sem az igénybe vett felhőszolgáltatás típusa, és a között, hogy van-e szükség IT-szakemberre.

Más eredményre vezet azonban, ha részletesen elemezzük az igénybe vett ITszolgáltatási típus és szükséges IT-szakember csoport közötti kapcsolatot (lásd: 8. táblázat).

\section{8. táblázat: Kereszttábla-elemzés}

\begin{tabular}{|c|c|}
\hline Kereszttábla elemzés SPSS mutatói & Értékek \\
\hline Person-féle Khi-négyzet statisztika & 0,015 \\
\hline Kramer V & 0,361 \\
\hline Lambda asszociációs érték & 0,227 \\
\hline Korrigált maradék (Csak IT szakembert), csak üzemeltető & 3,0 \\
\hline Korrigált maradék (Csak IT szakembert), fejlesztő és üzemeltető & $-3,2$ \\
\hline Korrigált maradék (Infrastruktúra), csak üzemeltető & $-2,2$ \\
\hline Korrigált maradék (Infrastruktúra), fejlesztő és üzemeltető & 2,5 \\
\hline
\end{tabular}

Forrás: Saját kutatás, SPSS

Az igénybe vett IT-szolgáltatás típusa és a szükséges IT-szakember csoport között gyenge közepes szignifikáns kapcsolatot állapíthatunk meg. A Lambda mutató alapján megállapíthatjuk, hogy ha ismerjük az igénybe vett IT-szolgáltatási típust, akkor 22,7 \%-ban elöre jelezhető a szükséges IT-szakember csoport. A Kereszttábla megoszlás szerinti vizsgálata azt mutatja, hogy amennyiben a vállalkozás csak IT szakember-szolgáltatást vesz igénybe, akkor a csak üzemeltető változót vonzza, míg a fejlesztő és üzemeltető szakembercsoport együttes alkalmazása változót szignifikánsan taszítja. Amennyiben az igénybe vett szolgáltatás infrastuktúra, akkor a fejlesztő és üzemeltető változóval jelentkezik a szignifikáns vonzás, míg a csak üzemeltető változóval a szignifikáns taszítás.

Az igénybe vett felhő alapú szolgáltatások típusa és a szükséges IT-szakember csoport között a Person-féle Khi-négyzet statisztika értéke $(0,002)$ alapján 
szignifikáns kapcsolat mutatható ki, elvetjük a függetlenséget feltételező nullhipotézist. A Kramer V mutató $(0,477)$ közepes erősségü asszociációs kapcsolatot fejez ki. A Kereszttábla megoszlás szerinti vizsgálata azt mutatja, hogy a csak tárhely és a teljes szolgáltatás igénybe vétele taszítja a fejlesztő és üzemeltető szakemberek együttes igénybe vételét, míg az infrastruktúra felhő alapú igénybe vételével szignifikáns vonzás figyelhető meg. A teljes szolgáltatás igénybe vétele vonzza a csak rendszerüzemeltető változót.

\section{Következtetések}

A vállalkozások számára a müködés és lehetőségek kihasználása érdekében döntő jelentőségü, hogyan sikerül kiépítenie információs rendszerét, milyen információtechnológiát alkalmaz, és hogyan tudja biztosítani ennek üzemeltetéséhez és fejlesztéséhez a szükséges IT- szakembereket. Kutatásunk témaköreivel részben más tanulmányokban is találkozhatunk. Vannak szerzők, akik a vállalatoknál alkalmazott információs rendszerekkel, és azok kialakítását befolyásoló tényezőkkel foglalkoztak, és olyanok is, akik az IT-szakember igényt vizsgálják. Kutatásunkban arra a kérdésre kerestünk választ, hogy a kettő terület hogyan kapcsolódik egymáshoz. Empirikus felmérésünkböl kiindulva elöször a vállalatoknál alkalmazott információs rendszert vizsgáltuk. Megállapítottuk, hogy kialakítását befolyásolja a vállalat mérete. Korábbi kutatásokkal összevetve kijelenthető, hogy hasonló eredmények születtek. De pozitív tendenciaként megfigyelhető, hogy a mikrovállalkozások körében is nő az informatikai alkalmazások, ezen belül az ERP rendszerek használata.

Fogalmi értelmezésre is felhasználtuk adatgyüjtésünk eredményeit. Megállapítottuk, hogy az ERP rendszerek nem fedik le a vállalkozások valamennyi funkcióját, és nem szolgálják ki az összes vezetési szintet sem. Tehát nem beszélhetünk teljes horizontális és vertikális integrációról. De véleményünk szerint ez nem okoz problémát akkor, ha a hiányzó területet lefedő szoftver beintegrálható, azaz tud kommunikálni az ERP rendszerrel.

Kutatásunk során vizsgáltuk, hogy a vállalati méret szerepet játszik-e abban, hogy milyen módon történik az informatikai alkalmazás (alkalmazói szoftver) kialakítása. Eredményeinkből megállapítható a kapcsolat. Tendenciaként megfigyelhetö, hogy egyre inkább háttérbe szorul a „dobozos szoftverek” alkalmazása és a saját fejlesztés. Ezek a kialakítási formák már leginkább csak a mikrovállalkozásoknál jelennek meg döntő többségben. De a vállalati méret növekedésével, és már a kicsiknél is egyre inkább azok a megoldások jelentkeznek, ahol az IT cégek saját keretrendszereit fejlesztik tovább, beépítve a vállalkozás speciális igényeit.

Empirikus felmérésünk adataiból megállapítottuk azt is, hogy a vállalat mérete befolyásolja ugyan azt, hogy van-e szükségünk informatikusra, de azt már nem, hogy az igény rendszerfejlesztő, vagy üzemeltető szakemberre vonatkozik-e. Tehát a kisebb és nagyobb vállalkozásoknál is jelentkezhet kereslet mindkét szakembercsoportra. 
Az IT-szolgáltatások és informatikusok iránti igény kapcsolatát elemezve kutatásunk alapján megállapítottuk, hogy a szolgáltatások igénybe vétele nincs hatással arra, hogy van-e szükségünk IT-szakemberre. A részletesebb vizsgálat alapján ugyanakkor kijelenthető, hogy az igénybe vett IT-szolgáltatási típus meghatározza az IT-szakember csoport iránti igényt. Ez a felhő alapú szolgáltatás igénybe vételénél is megállapítható. Amennyiben külső informatikus szolgáltatását veszi igénybe a vállalkozás, akkor jellemzően csupán üzemeltetők iránti kereslet jelenik meg. Ha infrastruktúra szolgáltatást vesz igénybe, akkor jellemzően rendszerfejlesztőre és üzemeltetőre is szüksége van. Ez a megállapítás a felhő alapú szolgáltatás ezen formájánál is fennáll. Abban az esetben, ha az IT-szolgáltatás használata felhő alapú, és a vállalkozás teljes körü felhőszolgáltatást bérel (azaz a szolgáltató alkalmazói szoftverét is ilyen módon veszi igénybe), akkor jellemzően csak üzemeltetők iránt támaszt keresletet. Tárhely és teljes körü szolgáltatás igénybe vétele esetén nem jellemző a mindkét szakembercsoport iránti igény.

Kutatásunk során hipotéziseket állítottunk fel, amely feltételezések vagy teljesültek, vagy nem (lásd: 9. táblázat).

9. táblázat: A Hipotézisek vizsgálatának eredményei

\begin{tabular}{|l|l|l|}
\hline \multicolumn{1}{|c|}{$\begin{array}{c}\text { Hipotézis } \\
\text { sorszáma }\end{array}$} & \multicolumn{1}{|c|}{ Hipotézis tartalma } & Elfogadjuk/Elvetjük \\
\hline 1. & $\begin{array}{l}\text { Feltételezzük, hogy a vállalati méret befolyásolja, az } \\
\text { ERP rendszerek használatát. }\end{array}$ & Elfogadjuk \\
\hline 2. & $\begin{array}{l}\text { Feltételezzük, hogy a vállalati méret befolyásolja, hogy } \\
\text { milyen módon történik az IT-alkalmazás igénybe vétele. }\end{array}$ & Elfogadjuk \\
\hline 3. & $\begin{array}{l}\text { Feltételezzük, hogy a vállalati méret meghatározza azt, } \\
\text { hogy szükség van-e informatikusra. }\end{array}$ & Elfogadjuk \\
\hline 4. & $\begin{array}{l}\text { Feltételezzük, hogy az IT szolgáltatások igénybe vétele } \\
\text { hatással van az IT szakemberigényre. }\end{array}$ & Elvetjük \\
\hline
\end{tabular}

Forrás: Saját szerkesztés

\section{Köszönetnyilvánítás}

Készült EFOP-3.6.1-16-2016-00012 sz. Innovatív megoldásokkal Zala megye $\mathrm{K}+\mathrm{F}+\mathrm{I}$ tevékenysége hatékonyságának növeléséért címü projekt támogatásával.

\section{Irodalomjegyzék}

Babbie E. (2013): The Practice of Social Resear. Cengage Learning, Wadswort.

Badinszky P. (2011): Információs technológiák alkalmazása. Digitális Tankönyvtár. $<$ http://www.tankonyvtar.hu/en/tartalom/tamop412A/2010-

0019_Informacios_technologiak_alkalmazasa/index.html>. (2019.03.28.)

Benkőné Deák, I., Bodnár, P., Gyurkó, Gy. 2008. A gazdasági informatika alapjai. Perfekt Zrt, Budapest.

Bocij P., Chaffey D., Greasley A., Hickie S. (2003): Business information systems. Technology, development and management for the e-business. Financial Times-Prentice Hall, Harlow New York.

Breyer J. (2018): European ICT Professional Role Profiles DRAFT version 2. CEN, Brussels. $<$ http://www.ecompetences.eu/>. (2019.03.28.) 
Budd J. M. (2011): Meaning, truth, and information: prolegomena to a theory. Journal of Documentation 67(1), 56-74.

Carifio J., Perla R. J. (2007): Ten Common Misunderstandings, Misconceptions, Persistent Myths and Urban Legends about Likert Scales and Likert Response Formats and their Antidotes. Journal of Social Sciences 3(3), 106-116. <http://thescipub.com/PDF/jssp.2007.106.116.pdf>. (2019.03.28.)

Chikán A. (2008): Vállalatgazdaságtan. AULA Kiadó Kft, Budapest.

Cser L., Németh Z. (2007): Gazdaságinformatikai alapok. AULA Kiadó Kft, Budapest.

Csíkos Cs. (1999): Nem-paraméteres statisztikai módszerek alkalmazási lehetőségei a pedagógiai kutatásban. Iskolakultúra 9(2), 113-119.

Fliszár V., Bollók S. (2014): A saját testsúlyról alkotott önkép hatása az egyén sportolási és dohányzási szokásainak kapcsolatára. Statisztikai szemle 92(5), 474-489.

Giller T. (2014): ERP Integrált vállalatirányítási rendszer múlt-jelen-jövő. Underground Kft, Budapest.

Halassy B. (1996): Ember-információ-rendszer. Avagy mit kell tudni az információs rendszerekről? IDG Magyarországi Lapkiadó Kft, Budapest.

Hastie T., Tibshirani R,. Friedman J. (2009): The Elements of Statistical Learning. Data mining, Inference, and Prediction. Springer Science+Business Média, New York.

Hetyei J. (1999): Vállalatirányítási információs rendszerek Magyarországon. Computerbooks, Budapest.

Hetyei J. (2001): Vezetői döntéstámogató és elektronikus üzleti megoldások Magyarországon. Computerbooks, Budapest.

Horváth D., Mitev A. (2015): Alternatív kvalitatív kutatási kézikönyv. Alinea Kiadó, Budapest.

Kacsukné Bruckner L.-Kiss T. (2007): Bevezetés az üzleti informatikába. Akadémiai Kiadó, Budapest.

Kadre S. (2011): Going corporate. A geek's guide. Apress, New York.

Koloszár L. (2009): Információrendszer fejlesztése, bevezetése és sajátosságai a vállalati gyakorlatban, különös tekintettel a kis- és középvállalkozásokra. PhD Thesis. NYME, Sopron. <http://ilex.efe.hu/PhD/ktk/koloszarlaszlo/disszertacio.pdf>. (2019.03.28.)

Koloszár L. (2013): Vállalati információs rendszerek. NYME Kiadó, Sopron.

Komló Cs. (2013): Információs rendszerek tervezésének módszertana. Médiainformatikai Kiadványok. Eszterházy Károly Főiskola, Eger.

Morgan G. A., Leech N. L., Gloeckner G. W., Barrett K. C. (2013): IBM SPSS for Introductory Statistics. Use and Interpretation. Routledge Taylor \& Francis Group, New York.

Nagyné Halász Zs., Gubán M. (2016): Az információs rendszer és fogalomrendszere. In: Csillag, S. (ed.) Alkalmazott Tudományok III. Fóruma Budapesti Gazdasági Egyetem, Budapest. 525-537.

Nicolescu V. et. al. (2007): SAP exchange infrastructure for developers. Galileo Press, Boston.

Raffai M. (2003): Információrendszerek fejlesztése és menedzselése. Novadat Kiadó, Győr.

Repschläger J., Zarnekow R. (2011): Studie: Cloud Computing in der IKT-Branche. Status- quo und Entwicklung des Cloud Sourcing von KMUs in der Informations- und Kommunikationsbranche in der Region Berlin Brandenburg. Universitätsverlag der TU, Berlin. <https://depositonce.tuberlin.de/bitstream/11303/3116/1/Dokument_32.pdf>. (2019.03.28.)

Repschläger J., Zarnekow R. (2011): Status-quo und Entwicklung des Cloud Sourcing von KMUs in der Informations- und Kommunikationsbranche in der Region Berlin Brandenburg. Universitätsverlag der Technische Universität (TU), Berlin.

Sajtos L., Mitev A. (2007): SPSS kutatási és adatelemzési kézikönyv. Alinea Kiadó, Budapest.

Sasvári P. (2010): The development of information and communication technology: An empirical study. University of Miskolc, Faculty of Economics, Miskolc.

Sasvári P. (2013): Az üzleti információs rendszerek használatának jellemzői a magyarországi és ausztriai kis- és középvállalkozások körében. In: Karlovitz, J. T. (ed.) Ekonomické štúdie - teória a prax. International Research Institute, Komárno. 358-368. 
Sasvári P., Rauch W., Szabó J. (2014): Diverse reasons for implementing business information systems. The example of typical usage patterns of business information systems among Austrian and Hungarian business enterprises. LAP Lambert Academic Publishing, Saarbrücken.

Szabó Gy., Benczúr A., Molnár B. (2013): ERP-rendszerek a számítási felhőben (Cloud Computing). A felhőtechnikával összefüggő új ERP-kiválasztási kritériumok elemzése. Vezetéstudomány XLIV(11), 62-70.

Szabó I. (2013): A felsőoktatási képzések munkaerő-piaci szempontból. Vezetéstudomány. XLIV(11), 52-61.

Szepesné Stiftinger M. (2010): Rendszertervezés 1. Az információrendszer fogalma, feladata, fejlesztése. Digitális tankönyvtár. <http://www.tankonyvtar.hu/hu/tartalom/tamop425/ 0027_RSZ1/index.html>. (2019.03.28.)

Székelyi M., Barna I. (2002): Túlélőkészlet az SPSS-hez. Többváltozós elemzési technikákról társadalomkutatók számára. Typotex Kiadó, Budapest.

Sziray J., Gaul G. (2006): Vállalati információs rendszerek I. Universitas-Győr Kht, Győr.

2004. évi XXXIV. törvény a kis- és középvállalkozásokról, fejlődésük támogatásáról. <https://net.jogtar.hu/jogszabaly?docid=a0400034.tv>. (2019.03.28.) 